\title{
Why Participation Matters: Communal Drinking Water Management in Bolivia and Ecuador
}

\author{
Maria Teresa Armijos and Anna Maria Walnycki
}

\begin{abstract}
In the past 30 years, Drinking Water Users' Associations (DWUAs) have emerged in peri-urban and rural areas in Bolivia and Ecuador where public utilities do not operate. While recognising the challenges to service provision and the problematic around the role of the state that exists in both countries, this article seeks to understand why and how local participation in drinking water systems has been so important for the formation of newly formed peri-urban and rural communities in both Andean nations. It argues that through participation in collective (communal) activities and decision-making, communities are constructed. This article will highlight, through our own experiences, why it became so important for us as researchers to participate in communal water management activities during fieldwork.
\end{abstract}

Drinking Water Users' Associations (DWUAs) were first established in the Andes as part of corporatist policies to expand services into areas where the state did not have much presence. However, over time and as a result of neoliberal reforms during the 1980s and 1990s, these associations became a very common form of water provision for recently settled communities in rural or newly formed peri-urban neighbourhoods. Today, it is estimated that there are around 6,000 DWUAs in Ecuador and approximately 28,000 community water providers in Bolivia (SAPSyRS 2010).

This article explores the role that participation in DWUAs plays in the construction of community in two quite different contexts in Ecuador and Bolivia. The community, or comunidad, is understood as the result of a process of defining rights over land and other resources, which necessarily entails determining social as well as territorial boundaries which can, and do change over time (Ibarra 2004). This latter meaning is central to the argument of this article, i.e. 'community' is not a descriptor or fixed condition; it needs to be strived for; it takes time and energy to construct.

This article draws on ethnographic data gathered in Ecuador during 2008/09 and the Zona Sur of
Cochabamba, Bolivia, in 2009-11. We adopted ethnographic and participatory methods to understand the development and role of one DWUA near Otavalo, Ecuador and one peri-urban DWUA in Bolivia, Agua Sur, which provides for the community Villa 15 de Febrero. ${ }^{1}$ This was part of two separate doctoral investigations into the development of reforms around the right to water in Bolivia and citizen rights and water in Ecuador.

The first section provides an introduction to collective water provision in the Andes and to the role that different actors play within these systems. The second section presents the case studies and reflections on our fieldwork experiences. The last section discusses the importance of participation in collective water management and the implications of conducting fieldwork in places where the local residents manage their own water systems.

\section{Managing drinking water at the local level in the Andes}

There is no one particular or distinct DWUA in the Andes, but a range of practices, normative schemes and traditions are employed to manage water. Each association or group borrows and reinterprets norms and laws from the state, traditional realms, and even from local 
development projects (Boelens et al. 2006). Having access to water is generally divided into two important sets of rights. There are communal/ neighbourhood rights to a particular water source generally granted by the state, and there are rights and rules set by the DWUAs to distribute water between its members (Boelens and Doornbos 2001). A recurrent characteristic is that rights to water and management decision-making are 'earned by those who work in the communal labour work parties, who participate in the water users' organisation, and who pay their dues according to collectively established contribution rates' (Boelens and Gelles 2005: 319). What needs to be highlighted here is the importance of having rights to decision-making. These rights depend on the extent to which an individual participates in communal activities. Water control and distribution is not always straightforward or equitable, it also involves struggles and open conflict. Contestation takes place over physical distribution of water, over the content of management rules, rights and regulations.

Some scholars have argued that excessive obligation and autonomy on the part of the communities, as is the case in water provision in rural and peri-urban communities in Ecuador and Bolivia, takes away the responsibilities of the state vis-à-vis its citizens and even supports the commoditisation of basic resources (Swyngedouw 1997, 2005; Pacari 1998). For some, 'governments - sometimes deliberately - alleviate themselves of certain responsibilities by expecting civil organisations to carry out those tasks' (Marquardt 2012: 179). Furthermore, it is suggested that excessive community participation/responsibility in service provision can lead to unequal access to resources as well as unequal experiences of citizenship (Marquardt 2012). This becomes evident when looking at the differences between urban, peri-urban and rural residency in Ecuador and Bolivia where the rights and responsibilities tied to accessing services are clearly different. Rural and peripheral communities are expected to contribute and organise to accessing water, while urban or better-off neighbourhoods, whose water is provided by state-run water companies are not. This model of service delivery clearly begs the question of whether or not it encourages social equality and inclusion.

While recognising the significance of this argument, this article highlights that the absence of state support has resulted in the emergence of a complex system of water rights and a strong sense that water should be managed locally to the extent that DWUA members see their participation in service provision as a right. This is evident in the case of the Bolivian periurban DWUAs that are unwilling to integrate into the formal municipal water governance model, and in Ecuador where hundreds of DWUAs are opposing a proposed water law, which, according to them, would take away decision-making power from local associations.

Conducting fieldwork in places where participation is a necessary precondition to accessing water and other services also gives us a unique opportunity to reflect on the implications of participation. It allows us to understand why and how 'participation' needs to be conducted and understood in the context of local norms, rules and expectations. Thus in the following sections, we will show that in order to gain the 'right' to conduct research in these communities, it became very important for us to physically take part in the communities' workdays or scheduled work parties organised to maintain the water systems or other local services.

\section{Introducing the Drinking Water Users' Associations in Ecuador}

In the context of the 1970s development agenda, increasing access to water became an essential part of the plan to expand services and state influence in small towns and villages in Ecuador. Consequently, the Ecuadorian Institute of Sanitary Works (IEOS), which was created in 1965, became the main institution supporting the construction of piped water systems in rural and urban areas. The original arrangement determined that once the water network was finished, in urban areas the local municipality would be in charge of running and maintaining it, and the IEOS would play the equivalent role in rural areas. However, managing hundreds of systems in the countryside became almost impossible for this ill-equipped state body. There was a lack of funding but more significantly, the IEOS was affected by the difficulty of organising constant visits and doing maintenance in remote areas far away from its headquarters. As a response to this situation, the then military government of Ecuador established by decree the Ley de Juntas Administradoras de Agua Potable y Alcantarillado, or Law for Drinking Water and Sewerage Users' Associations. ${ }^{2}$ 
Although the DWUAs were formally introduced in 1979, similar systems for administering and regulating shared water resources already operated in most rural areas. For example, there were well-established acequia, or channel users' organisations, that regulated how much and how often each member could use the channels to irrigate fields and water their animals (Ruf and Gilot 1995). The novelty of the model introduced by the law in 1979 was that it specifically targeted water infrastructures for human consumption, and specified that each association had the right to create their own rules and that they could gain legal recognition by the state. During the 1990s when the Ecuadorian government, like their counterparts in other Andean nations, embarked on a process of market-oriented reform, the IEOS disappeared and its sanitation programmes were transferred to the Ministry of Urban

Development and Housing (Ministerio de Desarrollo Urbano y Vivienda - MIDUVI), resulting in less state support and increased responsibilities for the local communities. The case of the Mojandita de Curubi DWUA located near Otavalo, Ecuador shows how these processes unfold at the local level.

Home to approximately 500 residents, Mojandita de Curubi is a new settlement on mountainous terrain on the slopes of Mount Mojanda at an altitude of 2,600-3,000 metres above sea level. Although Mojandita is only $3.5 \mathrm{~km}$ from Otavalo, it is outside what is considered the urban perimeter of the town. This community, a mix of Quichua indigenous and mestizo individuals (mixed race or individuals of combined European and Amerindian descent) was founded by poor peasants who migrated there from other areas in the 1960s and 1970s to buy small plots of land from what used to be a large land estate, Hacienda Mojanda. Although present-day households' livelihood strategies are varied and include jobs in the town and other industries in the area, most families in Mojandita have 1-3 hectares of land where they harvest a variety of crops for their own consumption as well as for the market. Through communal labour, and with aid from the Ecuadorian state institutions and NGOs, Mojandita's residents have been able to obtain a range of services such as a primary school, a health centre, electricity and piped water. An account of the introduction of piped water to the comunidad follows - specifically examining the effects and meaning of community as a formal organisational structure where rights and obligations have been established over time, and where the community members have built the system themselves.

During the late 1970s the IEOS planned to provide material and technical support to build the water system in Mojandita de Curubi on the understanding that the community would supply labour and find the water source. This meant that local residents would get involved in the building phase of the project, while leaving its design, planning and conceptualisation to the 'experts'. Under this model, participation was narrowly conceived and was restricted to local people contributing their labour to the construction of the system and attending meetings called by the community leaders (Borja Narajo 2002: 52-6).

Despite the approval from the IEOS, getting the project started was not a straightforward process and at first the majority of residents were reluctant to work to install the tanks and pipes that would bring water to their households. The unwillingness to work had to do with practicalities and the likelihood of change. People wondered whether the promise would ever become reality and, most importantly, if it would be worth providing free labour towards that end. To gather the necessary support, local leaders called various general community meetings and went from house to house talking to the residents. Rita Chicaiza, an indigenous women in her late fifties whose now deceased husband was a former community leader, describes the effort undertaken by him to convince people to work:

\section{My husband who spoke Quichua and Spanish, used to say: 'The water is going to pass through your home, in your doorstep you will have the tap, it will not be far away like in other comunidades. This will come to each household, you should take it with a good attitude, you should not reject it just like that... I have called you to the meetings, and you don't want to participate, but you are still in time, there is still time, we have to build small tanks, reservoirs, there is still time to help covering the pipes, laying tubes, there is time, keep working, keep supporting, don't be like that, think that you will have water here in your doorstep.' Like that, talking to them, he managed to convince people to work, and the water was installed...}

Once the majority of the comuneros, or community members, in Mojandita de Curubi agreed, the 
piped water system was built in several phases using the minga arrangement. Traditionally across the Andes, agricultural and building activities that require intense labour have been done by calling for a work party, or minga (Quichua term used in Ecuador). The minga has been the usual way of helping each other during the planting and harvesting seasons, when more than the individual household's labour is required (CEPCU 1999). While mingas for agricultural activities are no longer so usual, mingas related to communal resources or to building and maintaining different kinds of infrastructure at the local level are a common practice in the Otavalo area (ibid.).

Although at first people in Mojandita de Curubi were reluctant to work, the fact that they ended up building the system themselves is significant. It is because of collective work that today residents of Mojandita de Curubi have a school, electricity and water. This also means that 'progress' (progreso), as it is sometimes called, or what is understood as development for the community, is the product of their own effort. Margarita Chancozo describes the significance of collective effort:

\section{When they started looking for water they found it up in the mountain, a water spring, and then the piped water project began. Then we worked, everyone did, we did it through the minga. This water is product of the minga, of the effort of all the community members. We are always working. It is our collective strength, men and women working. I worked too, also my husband, making the tanks to collect drinking water.}

While collective work has allowed marginal areas such as Mojandita to improve their infrastructure and service provision and build a sense of community, it has also established a mechanism of resource access, or water rights. It is through participating in or contributing to the construction of infrastructure that users establish collective and individual rights to access water. On one hand, as the community builds a system, they acquire the right to benefit from and use a particular source of water vis-à-vis other potential users (neighbouring communities, farms, industries, etc.). This right is generally recognised by the state in the form of specific drinking water concessions granted to the community. On the other hand, during the construction process, and based on the amount of time, effort and work invested, households gain the right to access the resource at the household level. In other words, the households that actively took part in the minga[s] to construct and maintain the water system gain the right to use the service. Acquiring the right to access water also means gaining the right to define the criteria of how, when and why to include (or exclude) different actors in the arrangement (Boelens and Doornbos 2001: 284).

Given how central participation is in establishing water rights, 'measuring' it has become a vital aspect of the arrangement. ${ }^{3}$ Since building infrastructure normally requires more than one outing or minga to be completed, the raya system, or working turns, is used. The raya is a counting method to determine how many times a household has contributed. At the beginning of each minga, the community's secretary calls the names of all heads of household registered on a list, and notes if they are present by drawing a line (raya) next to their names. Each household has the obligation to send a man, woman or young adult to the minga in order to be registered as having contributed a day's work, i.e. to obtain a raya. Because there are particular jobs that require more effort than others, participating in one difficult minga can account for more than one raya. Also a household can contribute more than one person in a particular minga day, which would then count for two rayas. Alternatively, residents might contribute in kind, with vehicles to transport materials or with the actual cement, sand, etc. needed for construction and maintenance of the system. Households that are unable to contribute or work because its members are too old or ill are allowed to contribute with food and/or drink, and in some instances do not have to participate.

\section{Counting participation: negotiating communal membership}

At the beginning of the workday, people start gathering outside the DWUA's house around 7.30am. People gradually arrive, each with a tool (shovel, machete, hoe) for what could arguably be the most important aspect of the minga: calling the list. All households that have water connections are on the register, listed by the name of the 'head of household' (which may be a man or woman). As the list is called out by the community secretary, people pay close attention to hear not only their name called out but also other people's. It is the time when contributions are publicly scrutinised and 'publicly acknowledged' (Mayer 
2002: 128). Did someone come from that household? Who was sent? Should they really be counted? As Mayer (ibid.) argues, this is the moment when the minga participants ensure that 'everyone share[s] equally in the tasks the community impose[s]. Work performed [has] to be counted'. Slowly, the secretary goes through the list, marking a line next to each household that has sent someone and leaving blank spaces next to the names of those who have not. It is not uncommon to hear expressions of discontent and discussions of whether young boys/girls (around 13-14 years old) should be counted. Food contributions are also evaluated and are only accepted if the person is ill or widowed.

My presence did not pass without notice either, and as $I^{4}$ nervously replied 'aquí' (here) after my landlady's name was called out, Jaime Anrango, the comunidad's president, quickly commented: 'Are you going to work?'. On the advice of Don Julio, the DWUA operator, I had decided that in addition to attending the minga to observe, I would also work and justify my presence as a resident in this community. My decision to attend the minga had two aims: in addition to 'gaining' the right to access water, I also wanted to gain the 'right' to live and conduct research in Mojandita. In this context, Jaime's 'you' could have been very damaging: Are you, a city girl, really going to work? Are you able to work? How would you contribute? The question, in addition to exposing my position as an outsider in front of the community residents also placed me in the category of those who live in Mojandita but contribute in 'other' non-labour forms. Was I really thinking of digging a hole or cleaning the water tanks? In theory I had not been asked to be there, and I could have just asked the landlady to pay the fines for not attending the mingas, as she always did, or contribute to the community by helping them draft official letters (something that was actually suggested to me when I first arrived).

Just when all my modest attempts to take part in a central community activity seemed to be failing, Doña Consuelo, a middle-aged member of the community, intervened. Almost yelling, she said rather defiantly to the president of the comunidad: 'Are you saying that because she is a woman she can't work? You know that we can and we do contribute to these mingas as well!' Jaime just nodded and told the secretary, Maria Perugachi, to continue calling the names on the list. I felt great relief, which was reinforced when I looked around me and saw some familiar smiling faces. On a personal level, the comment had a special meaning. A few months earlier, during the start of another minga, when I was introduced to the local residents for the first time as a researcher who was going to work on water issues, it had been Doña Consuelo who had questioned my intentions. In front of all the people waiting for the list to be called out, with her usual defiant tone, she asked if I was there to spy on their water system and to see whether it would be possible to pipe their water to the nearest town of Otavalo. Not long before my arrival, the mayor of Otavalo had expressed similar intentions, which made studying water-related issues controversial at that particular time.

In the context of the contestations that take place during the minga and the comunidad's everyday events, Doña Consuelo's remarks were not random. By questioning Jaime's comment on my capacity to work, not only did she help legitimise my presence there but also used it as an opportunity to legitimise all the women that participate in the minga, including herself. Although women's labour contribution is accounted for, men are naturally able to do heavier work, which is necessary during the mingas and therefore often considered more valuable. Also, Doña Consuelo's reply to the president had a significant effect in terms of my presence there; it 'equalised' me in relation to the other women in the community. My background and status (urban and privileged) as well as my physical appearance (taller than most present there) were put aside. I became one more woman contributing her labour towards the minga effort. My role as a contributor would be counted in the same way as that of Margarita Chancozo, a middle-aged Cayambi indigenous woman, or Adriana Perugachi, a young mestizo mother working at the local hotel.

What Doña Consuelo did for me with her comment, the list does for people's status in general. As a document that contains records of labour contributions, credited next to each household with a series of lines, it equalises different households or 'makes people convertible' (Colloredo-Mansfeld 2009: 104). A young, unemployed indigenous woman like Ana is accounted for in equal terms to Juan Guerrero, a white-mestizo man in his forties who works for one 
of the local hotels, Casa Mojanda, as a tourist guide. Regardless of the job they perform during the minga, both would gain one raya next to their household's name. Because they fulfil the same function (a raya on the list), 'households frequently make use of this reductionism to adapt whatever disposable resources they have to get on the list' (ibid. 2009: 104). In this light, hearing the list is read out is crucial to know who and how others are contributing.

From an individual's point of view, the concern with equity [is] a matter of making sure that the others contribut [e] as much as oneself or, from a more selfish perspective, that one contribute[s] only as little as others would let one get away with (Mayer 2002: 128).

At the communal level though, list-keeping transcends individual households' concerns about equality and becomes a central element in the creation and maintenance of the comunidad's physical and symbolic boundaries.

Lists reflect the ability of each community to improve and access resources through individual household contributions and accumulation of rayas. Crucially, however, for the system to function and for it to be sustainable in the long run, people need to participate in collective activities. They need to take part in the mingas and continually legitimise the system. In this sense, water has become fundamental for the minga to retain its function and for the list to exist. In the past few years, and due to a decrease in attendance, local authorities decided to make a joint DWUA and Community Council (cabildo) call for work parties, which has resulted in a positive increase in people's participation in communal activities. The reason behind these improvements is that when the call includes the DWUA the right to access water is automatically maintained by participating in all mingas regardless of their (water or non-water) nature since participation is accounted for using the same lists. In other words, to maintain the right to access water, residents are required to attend all mingas irrespective of their purpose. Thus, it is possible to say that water has become instrumental in controlling labour and to a large extent in keeping the minga system afloat.

Despite the importance of DWUAs in securing participation in the workdays or mingas, it is necessary to note that collective forms of organisation do not guarantee equality or efficiency in water access and distribution. For instance, some residents are not able to access water because they are too poor to 'get connected' to the system, to be included in the community. Women are also being left out, especially from decision-making processes, as they remain excluded from most leadership roles. There are also problems with fund management and abuse of power within the comunidad which could undermine and even endanger collective forms of social organisation in the long run.

Nonetheless, it is also possible to say that the laws and reforms introduced since the 1970s combined with a lack of state support have led the DWUAs to gain significant responsibilities and political position as local organisations. DWUAs have strengthened their power at the local level through the control of water resources. They gradually and perhaps unintentionally become more independent and autonomous. At the core of this process is participation of the system's users in building and maintaining the infrastructure. If this capacity was taken away from local communities, they would also lose their ability to establish allocation rights and tariffs. Most importantly, they would not be able to maintain decisionmaking power over their resources.

\section{Drinking Water Users' Associations in the Zona Sur of Cochabamba, Bolivia}

DWUAs have existed in Cochabamba, Bolivia, since the 1970s in suburban and peri-urban regions of the city that the municipal water utility, SEMAPA (Servicio Municipal de Agua Potable y Alcantarillado de Cochabamba) does not provide to. SEMAPA's capacity to deliver water to the whole municipality has been undermined by insufficient investment, failing infrastructure, insufficient capacity to address clandestine connections and internal corruption. In the absence of a universal provider, diverse community-managed water systems flourished in suburban and poorer peri-urban communities alike. These organisations emerged as a result of support from the church during the 1990s, and were supported by NGOs during the 2000s. These DWUAs have galvanised around communitybased uses and customs; some DWUAs have mobilised in opposition to municipal models of provision, instead advocating a model of co- 
produced water services with the state. Since the election of Evo Morales, reforms to the water sector have led to policies, which, in principle, protect and provide support to community-led water providers. Despite these endeavours and reforms, this section demonstrates that there are certain factors and dynamics that are distinctive to peri-urban areas, which can undermine DWUAs and community-led institutions.

Community-led water provision is prevalent across rural and urban areas in Bolivia, reflecting the absence of universal public provision. In Cochabamba alone there are an estimated 500-600 DWUAs (World Bank 2007) and around 150 of those are in the peri-urban southern zone of Cochabamba known locally as the Zona Sur. Community-led infrastructure and basic service provision is widespread in the Zona Sur; many of the communities began as or continue to be informal settlements that were established illegally and are not recognised by the state, but which have formalised over time. This section focuses on one of these DWUAs, Agua Sur, which provides to marginalised periurban communities in the Zona Sur.

\section{DWUAs flourished in the Zona Sur during the} 1990 s as a result of intense inward migration to the region during this period after the closure of several mining centres, and more recently a decline in the profitability of agriculture in rural areas in Bolivia. Locally, the uses and customs that evolved around the mining unions and traditions are often referred to as being pivotal in the development of collective community-based strategies for development in the Zona Sur. In reality, the demographically diverse communities that were formed in the Zona Sur reveal that communities were not simply mining communities that were transplanted to the Zona Sur; communities were formed as a result of members working together to develop collective solutions for basic service provision. The time and energy invested in this process provided the foundations for many of the communities in the Zona Sur, but this is an ongoing process that requires maintenance and re-affirmation. In the complex, dynamic peri-urban reality of the Zona Sur, the institutional sustainability of communityled DWUAs can be somewhat fragile; families may move from rural areas to the Zona Sur during term time to study or for seasonal work, and so they are not always around to regularly participate in communal activities. While periurban communities began as informal settlements consisting of one-room adobe houses, finances through remittances from abroad or from cash crops such as coca has meant that some families are now relatively wealthy and prefer to buy in services as opposed to participating in 'oldfashioned' community services. The impact that this has on collective initiatives in one neighbourhood or barrio in the Zona Sur, Villa 15 de Febrero, is now explored.

Villa 15 de Febrero was established around the collective construction of local infrastructure and basic services, including roads and pathways, street lighting and water provision, but the church and several key NGOs have played a role in supporting community development. One such initiative was led by the Catholic Church in the late 1990s to encourage the development of DWUAs in an attempt to provide cheaper, more reliable water than that provided by the water vendors in Villa 15 de Febrero. Agua Sur was one of the DWUAs formed as a result of this initiative in 2001. The committee was established on communitarian principles for the good of its members:

Agua Sur is a non profit making civil association, of communitarian character that represents the interests and responsibilities of the community in relation to basic services (water) (Agua Sur Norms and Regulations 2001).

Consequently, Agua Sur provides reduced tariffs to organisations in the barrio providing a service that benefits the community, such as the nursery or the community hall, while members pay cost price for their water. Participation in the management of the committee has been used as a method of fostering ownership amongst the members. Members have to pay an initial fee of US $\$ 40$ for membership of the DWUAs and this money was used to develop the system. One household representative is then required to participate in meetings and workdays and those who do not are fined the equivalent of US $\$ 0.40$.

Agua Sur serves over 300 households in the barrio. This service is cheaper than the cost of water sold by vendors, but more expensive than the cost of water in the city centre. With impetus from the church and funding and labour from the community, the committee excavated a local 
well and constructed a local pipeline that supplied water directly to each member household. Barrio elders talk proudly about being involved in the water committee from the outset:

There were some members who didn't believe that there was water there. They asked where is the water going to come from and honestly they didn't want to spend the money. But I believed, I put $\$ 40$ in at the very beginning. (Julia, $\mathrm{OTB}^{6}$ secretary)

The members constructed the physical foundations of the system and the community; they dug ditches for pipelines and constructed the water tank; they participated in and worked for this project collectively, and they reflect on it proudly.

DWUAs flourished during the early 2000s to the extent that in 200649 DWUAs federated to form a critical mass called ASICASUDD-EPSAS (the Associations of Water Systems of the Southern Zone). The federation works to capacity build water associations, and lobbies for the co-management of water services with the state. This approach is premised on the idea that DWUAs should oversee the provision of water at the community level, with some support from the state, often in the form of capital or technical expertise. Over time it has become a platform and gatekeeper to the peri-urban, as evidenced through NGO funding and projects and government policies that seek to understand and support peri-urban DWUAs as part of reforms that have been introduced by Evo Morales to incorporate and capacity build community water providers (MMAyA 2008). This has meant that DWUAs not only play a role in local water management, but also have the potential to participate and contribute to the development of water policies and planning for water provision in the region.

The DWUAs belonging to ASICASUDD-EPSAS are diverse in memberships, organisational structures and the uses and customs that have evolved over time. They serve between 60-900 members and some have more abundant and cleaner water sources than others. The management structure of each DWUA also varies and reflects the uses and customs that communities have developed and institutionalised around their water systems. The DWUAs and ASICASUDD-EPSAS believe that without the participation of the community in the management of water provision, their water needs will not be met, having been marginalised by the state for so long. Community-led water provision was buoyed by the post-water war climate. During the Water War in 2001, irrigator groups and community-led potable water providers took to the streets alongside urban Cochabambinos to protest against the privatisation of water sources and services across the municipality. The creation of a private concession, a precondition of the International Monetary Fund (IMF) and World Bank debt relief packages developed at the time (see Crespo 2003; Olivera 2004; Schultz and Draper 2009 for further discussion on this). The contract was awarded to the sole bidder, Bechtel, which was granted exclusive rights to all the water sources in Cochabamba including the aquifer in the region. The uprisings continued for over a year and eventually led to the concession being overturned.

Following the Water War it became politically unviable to usurp or undermine community-led water providers; indeed, laws were passed that protect and formalise the usufruct rights of communities and their rights to provide water services. Meanwhile Cochabamba became a hotspot for NGOs and activists looking to support DWUAs. Further, since the election of Evo Morales in 2006, there have been several funding initiatives that suggest that DWUAs could potentially be supported as alternative providers in the peri-urban southern zone. In practice, while state rhetoric around community management is strong and legislative initiatives have been undertaken to protect DWUAs, support has yet to materialise in a practical or strategic manner. DWUAs continue to rely on support from NGOs and government initiatives, but ultimately their institutional sustainability depends on the participation of the community.

\section{Physical challenges facing DWUAs today}

While DWUA members recall how the DWUA initially provided sufficient water of reasonable quality, over time the water has become increasingly saline as the aquifer has been overexploited by increasing numbers of informal water systems and contaminated as a result of industries in the region and a lack of sanitation (Ghielmi et al. 2008). Nonetheless, DWUA members continue to participate because it provides cheaper water than the water vendors. 
Further, as the DWUA is a member of ASICASUDD-EPSAS there is a chance that the community may, one day, receive water through a proposed co-production initiative where

SEMAPA would supply water to the DWUAs from a new dam at Misicuni, which is projected to be completed in 2015. However, current water shortages, contamination, and an extensive upgrading programme mean that committee members have had to use water vendors to supplement their water needs. Despite the poor water quality and the unreliability of the service, members are dedicated to the DWUA and are willing to participate in its upkeep and management.

\section{State legitimacy as provider}

Despite the physical challenges facing the DWUA, members are reluctant to recognise that the state will improve water provision in the Zona Sur. There is a sense amongst those who participate in the DWUA that they have been let down by the state so many times that the community has to take responsibility for water services, much like they have developed other basic services in the barrio. The failure of the state to provide basic services legitimises the discourse that the community is best placed to provide basic services such as water provision in the Zona Sur, as explained by one barrio elder:

I arrived at the barrio 30 years ago, when there was nothing here, we cleared cactus and built roads together. So many local politicians have come to this barrio and promised to pave our roads, but we have had to do everything, pave roads, bring electricity, and sort out the water supply... The communities of the Zona Sur have had to manage their resources and so have become good at it, we should be supported in doing this.

Associations are keen to defend their right to participate in the management of water services in the Zona Sur because they fear that if they leave it in the hands of the state they will lose all they have achieved to date. The only infrastructural project to have been completed by the public utility SEMAPA in the Zona Sur is the Japanese aid agency-funded expansion project. This project extended a system of pipelines to 18 barrios in the south-west of the Zona Sur. This involved developing infrastructure, including pipes, tanks and pumps for distribution of water and increasing the capacity of a local water treatment plant. The project was inaugurated by
President Morales, who ceremoniously opened the tap in September 2011, and was widely hailed in the press as a SEMAPA success story in the Zona Sur (Heredia 2011). One of the principal coordinators of SEMAPA's work in the Zona Sur since 1995 explained that, before the expansion project most of the communities that are part of the project relied on DWUAs or water systems run by residents' associations. Thus, when the network begins operating, the DWUA and residents' associations have requested that they retain control of the water system through a local meter installed for each barrio. The members will then take control of collecting funds because they are unwilling to relinquish the agency that they have over water provision in the region. A local committee leader explained this phenomenon:

We don't trust SEMAPA... SEMAPA provides water to district 7 with macro-meters 2.37 per $m 3$ - but was [sic] has happened is that SEMAPA has started charging for air, and in Villa Venezuela too. They do not always have water, sometimes it is only once a week, and they are being charged for water they don't use... so there are members who have seen this experience and they don't like it... the community has lost control of water provision, SEMAPA has connected directly to the pipelines. We have learnt that it is better if the community stays in charge of the distribution.

\section{Fragile peri-urban communities}

Despite the persistence of some DWUA members who maintain that the community is best placed to manage water provision, there are certain factors that undermine community-based institutions in the peri-urban area. There is a second means of accessing water in the Zona Sur, which is to buy water from vendors. Not everyone in the community is willing to participate in the management and supply of their water system.

As a result of the dynamic nature of populations in the peri-urban Zona Sur, communities are prone to sudden expansion or contraction. Further, some members are transient, only spending a few months of the year in the city, and the remainder of the time working in rural areas, making membership difficult. Transient community members are unwilling to participate, because they are unwilling to invest time in a service from which they cannot fully reap the benefits. Newcomers are welcome to join but negotiating membership can be tricky. Barrio elders that have contributed to numerous workdays feel that new members who have not 
been part of the development of the committee should make a US $\$ 200$ contribution to reflect the decade of human and financial investment that elder members have made. This proposal has been controversial, and is prohibitive for poorer people who move to the barrio.

The committee has never achieved universal provision. Some members have always relied on water from water vendors. The first pipeline that was built was developed for the streets that were populated during 2001. By 2012, the barrio had grown exponentially. The barrio is deeply unequal; while those who settled in the centre of the barrio have developed their houses into modern properties with water that is distributed throughout the house, those who have moved in at the edges tend to live in adobe huts and buy water in smaller quantities by the turil (200 litre barrel) as it is cheaper.

When the first pipeline was installed, there were lots of opportunities for members to contribute physically. When the committee had a new pipeline installed, they hired engineers and contractors to undertake the work under the direction of the committee director and secretary. This is an example of how opportunities for participating in the management of water provision have declined as solutions to water provision have become increasingly technocratic. In peri-urban regions of Cochabamba with more rural characteristics such as La Maica, where water (although saline) continues to be available, it is still possible for community members to participate in workdays, and participation in meetings is widespread. In Villa 15 de Febrero, where the region is more densely populated and water is scarce, the water committee has had to bring in outside water sources using a tanker, and people have begun to view the committee as a service because they have reduced opportunities to build and participate in the development of water provision.

Participation is a key element to the survival of the water associations, as evidenced in Villa 15 de Febrero. However, opportunities for participation in workdays have declined in the barrio of late and the workday system is quite different to the Ecuadorian minga. As the workdays happened less frequently because the system had been established several years before and much of the maintenance required engineers, there were less opportunities for the community to work together. The work required in the peri-urban area was quite different to that undertaken in rural Ecuador where there were general maintenance tasks such as cleaning the tank. In order to understand how people participated in the workdays, one of the first things I did in the barrio was to attend and take part in a collective activity.

\section{Gaining a 'sort of acceptance' in the barrio}

The water secretary had advised me a few weeks beforehand that she would call me when I was needed. She did just that unexpectedly one Sunday at about 5.30am: 'Anita, come down to the tank this morning, we are cleaning it out today'. I arrived and there were at least 50 people present, far more hands than the work required. We passed buckets up a pulley system, but mostly we watched as the younger men cleaned out the gunk from the water tank that was at least three storeys high. Nowadays workdays are few and far between. The community had dug trenches in the past but now engineers and contractors undertook much of the work. Consequently, the annual tank cleaning is something of an event that brings DWUA members together. That morning it doubled as an organising meeting. During other workdays in which I participated in the barrio I felt more useful, be it through clearing land for a new sports pitch or painting communal buildings. This workday appeared to be an opportunity for the community to come together around a task; there were many more people present than needed, but by showing up people reaffirmed their commitment to the DWUA and community-managed water in the barrio.

As a researcher, the cleaning of the tank was one of the first ways by which I was able to gain a sort of acceptance in the barrio. This was challenging at first as I was foreign, female and unmarried. Generally, across the barrios of the southern zone, residents were bewildered as to why I was on my own and childless. Men tended to be thrown by the fact that I had been 'allowed' to come to Bolivia on my own; one local taxi driver asked me why my father and partner had let me travel unaccompanied. Meanwhile, the women in the barrio were concerned that I didn't have children; I was told several times that, at the age of $28, \mathrm{I}$ had left it too late to have children, or needed to rush back to my partner to have babies as I was 
getting too weak to have children. But being a woman made it easy to undertake household interviews with women who stayed at home during the day, although at times not having a family and being single made some women in the barrio more wary of me. Being a woman also presented certain opportunities to me; it meant that men were less wary of me, and were willing to take time to explain their role and position in the barrio. Furthermore, participating in workdays and community activities across the barrio and undertaking household surveys and interviews meant that people became familiar with me, and I gained a sort of acceptance over time.

It should be emphasised that the barrios of the Zona Sur are difficult places not only to gain access to but also to understand. Like many periurban areas and informal settlements,

demographic information is unreliable or nonexistent and often undermined by the fact that there is a mix of permanent residents who are only there for seasonal work or during term time for studies. This, combined with a fear of crime and infighting between different parts of the community leads to social fragmentation. Gaining complete acceptance by the community would be impossible. One priest who had been working in the barrio for seven years told me over coffee one morning how happy he was to have been invited in for dinner by his next-door neighbour that day. They had been neighbours for seven years and it had taken that long to develop their relationship, but this was not unusual as residents tended to be suspicious of newcomers. Residents also tended to work long hours in the city and often lived in houses that were surrounded by high gates and walls lined with broken glass. Furthermore, the barrio did not provide many public spaces for congregation. Consequently, it would not be unusual for residents to not know the names of their neighbours, let alone invite them in for coffee. In sum, and in light of the fragmented nature of the community, the best I could hope for in this barrio was a 'sort of' acceptance. Participating in a workday like this was one way to make my face known to the community but also for them to begin to accept me.

\section{The implications of participatory DWUAs in newly formed marginalised communities}

Increased autonomy and community involvement in service provision can be seen as a way of relieving the state of its responsibilities as well as its financial obligations (Marquardt 2012; Mehta et al. 2007). It could even be said that transferring rights and responsibilities to local water user groups allows neoliberalism, or an agenda inspired by privatisation and decentralisation, to thrive. While taking these points into account, this article has aimed to examine how these increased 'responsibilities' have unfolded at the local level, and most importantly how they have influenced people's experiences of accessing water. We suggest that in the context of a history of marginality, acquiring services, especially through a self-help model, has had important consequences on the way in which local users claim and legitimise access and governance over natural resources.

As it has been explained in both case studies, local users are willing to maintain a form of water provision that requires high levels of participation, even when they are not very efficient or there are institutional problems. We argue that one way of understanding this phenomena is by looking at the other, non-waterrelated roles that DWUAs play at the local level. Water is one of the few resources that marginalised people can control and, most importantly, it gives them a platform through which they are able to organise. In the Ecuadorian case the prominence of collective work duties in creating social boundaries in rural communities becomes particularly relevant in the cases of post-land reform settlements, such as Mojandita de Curubi. Although a result of the transformations that took place in land tenure patterns after the land reform, these communities are not based on a shared history of struggles for land with neighbouring haciendas as other, independent indigenous communities or hacienda workers might be. Instead these communities, formed by residents who are coming from different ethnic backgrounds and who think of themselves as diverse, are products of the local residents' effort to build a place of their own, access services and resources and reassert control over them. It is precisely in the process of acquiring these services that communities like Mojandita strengthen their ties and boundaries. In this context, labour becomes particularly important and controlling it is vital.

Similarly, in Villa 15 de Febrero, the community was established in the absence of the state; poor 
residents were able to develop basic services by pooling resources and energies. The 'community' is evidently much more fragile than the

Ecuadorian case study. The population is subject to seasonal influxes and exoduses which can undermine community endeavours, as some members invest less time and resources more frequently than others. It is also apparent that local residents' aspirations can change as they become wealthier and less interested in participating in communal activities.

Furthermore, the proximity of the barrio to the urban centre means that community members have developed more 'urban' aspirations for the same rights and services that those who live in the centre of the city have. These phenomena combined with declining water levels and further contamination of the aquifer means that this community-based institution has become unsustainable. The community is still perceived to be the best governor of local water services, but this is increasingly perceived to be in partnership with the state, through co-produced water services.

In short, it is possible to say that acquiring infrastructure through local effort and work has created an important sense of responsibility, belonging, resource ownership and general improvement in both case studies. The

\section{Notes}

1 All people's names have been anonymised, while place names have only been anonymised in the Bolivian case study. Place names have been kept for the Ecuadorian location given that this does not pose a direct threat to the community members and that this research project was approved by the local community council.

2 'Ley de Juntas Administradoras de Agua Potable y Alcantarillado', Decreto No. 3327, Registro Oficial No. 802, 29 March 1979.

3 Participation is broadly defined and encompasses contributions in the form of labour, time, money, expertise, materials, etc. In the context of Andean practices this means establishment of locally operated domestic water arrangements has resulted in an important sense of community, provided a strong platform for selforganisation and a mechanism for allocating water rights, all of which are aspects of resource access and distribution which local residents consider to be central to their cultural and political practices.

Drawing from our experiences undertaking our $\mathrm{PhD}$ research in Bolivia and Ecuador, we have attempted to demonstrate that participation plays a key role in the development of DWUAs, and also that participation in collective activities within the community enabled us to be accepted as researchers. One of the principal challenges to undertaking in-depth ethnographic work is overcoming or at least reconciling your positionality so that you gain a level of acceptance within the community that enables you to undertake fieldwork. In the case of these communities, acceptance was only granted once we took part in the community activities and contributed with our effort and bodies towards the improvement of these places. We learnt that there was value in participating in community activities beyond those that were directly related to our research, because participation is a twoway process by which we gained acceptance and the community came to accept us.

equal reciprocal exchanges (of labour, money, etc.) that have allowed the community to gain access to different resources. When applied to the DWUAs it means sharing the responsibilities of building, maintenance and decision-making processes relating to the water infrastructure.

4 The research in Otavalo, Ecuador was conducted by Maria Teresa Armijos.

5 Community document.

6 OTB stands for Organizaciones Territoriales de Base (Grassroots Territorial Organisations), formal indigenous or neighbourhood organisations, established through the Popular Participation Law of 1994. 


\section{References}

Boelens, R. (2006) 'Las Múltiples Dimensiones de la Valorización del Agua en la Región Andina', in Andes. E. Isch and I. Gentes, Agua y Servicios Ambientales: Visiones Críticas Desde Los, Quito: Abya Yala

Boelens, R. and Doornbos, B. (2001) 'Derechos de Agua y Marcos Normativos Conflictivos', in R. Boelens and P. Hoogendam, Derechos de Agua y Acción Colectiva, Lima: IEP ediciones

Boelens, R. and Gelles, P.H. (2005) 'Cultural Politics, Communal Resistance and Identity in Andean Irrigation Development', Bulletin of Latin American Research 24.3: 311-27

Boelens, R.; Getches, D. and Guevara Gil, J.A. (eds) (2006) Agua y Derecho: Políticas Hídricas, Derechos Consuetudinarios e Identidades Locales, Lima: IEP ediciones

Borja Narajo, G. (2002) 'El Agua Potable en el Sector Rural: Un Analisis de las Formas de Intervension Social y de la Politica a Partir de un Estudio de Caso Maestria en Ciencias Sociales', Facultad Latinoamericana de Ciencias Sociales, Sede Ecuador

CEPCU (1999) Microcuenca Urumbilla. SAPISabiduria Comunitaria: Comunidades de Caluquí, Gualacata y Mariscal Sucre [Urumbilla Watershed. Community Knowledge: Caluqui Community, Gulacata Community and Mariscal Sucre], Otavalo: Centro de Estudios Pluriculturales Colloredo-Mansfeld, R. (2009) Fighting like a Community: Andean Civil Society in an Era of Indian Uprisings, Chicago: University of Chicago Press Crespo, C. (2003) 'Water Privatization Policies and Conflict in Bolivia: The Water War in Cochabamba (1999-2000)', PhD, Oxford Brooks University

Ghielmi, G.; Mondaca, G. and Luján, M. (2008) 'Diagnostico Sobre el Nivel de Contaminación de Acuíferos en el Distrito 9 del Municipio del Cercado en la Ciudad de Cochabamba y Propuesta para su Protección y Control', Acta Nova 4.1: 51-86

Heredia, J. (2011) '50 Mil Familias del Sur se Benefician con Red de Agua', Los Tiempos, 5 December

Ibarra, H. (2004) 'La Comunidad Campesino/ Indigena Como Sujeto Socioterritorial', Ecuador Debate 63: 185-206
Marquardt, K. (2012) 'Participatory Security: Citizen Security, Participation and the Inequities of Citizenship in Urban Peru', Bulletin of Latin American Research 31.2: 174-89

Mayer, E. (2002) The Articulated Peasant: Household Economies in the Andes, Cambridge: Westview Press

Mehta, L.; Marshall, F.; Movik, S.; Stirling, A.; Shah, E.; Smith, A. and Thompson, J. (2007) Liquid Dynamics: Challenges for Sustainability in Water and Sanitation, Brighton: STEPS Centre

MMAyA (2008) Plan Nacional de Saneamiento Básico 2008-2015, La Paz: Ministerio de Medio Ambiente y Agua

Olivera, O. (2004) iCochabamba!: Water Rebellion in Bolivia, Cambridge MA: South End Press

Pacari, N. (1998) 'Ecuadorian Water Legislation and Policy Analyzed from the IndigenousPeasant Point of View', in R. Boelens and G. Dávila (eds), Searching for Equity: Conceptions of Justice and Equity in Peasant Irrigation, Asen: Van Gorcum

Ruf, T. and Gilot, L. (1995) 'History of the Irrigation, the Constitution of Water Rights and the Role of the State and Peasants', Communities in Ecuadorean Andes, Fifth Common Property Conference: Reinventing the Commons, Bodo, Norway

SAPSyRS (2010) Programa Socio Aguay Saneamiento, www.miduvi.gov.ec (accessed 8 December 2010)

Schultz, J. and Draper, M. (2009) Dignity and Defiance: Stories from Bolivia's Challenge to Globalization, Berkeley CA: University of California Press

Swyngedouw, E. (2005) 'Governance Innovation and the Citizen: The Janus Face of Governance-beyond-the-State', Urban Studies 42.11: 1991-2006

Swyngedouw, E. (1997) 'Power, Nature and the City: The Conquest of Water and the Political Ecology of Urbanization in Guayaquil, Ecuador', Environment and Planning A 29.2: 311-32

World Bank (2007) Estudio Sobre Operadores Locales de Pequeña Escala en Áreas Periurbanas de Bolivia, La Paz 